\title{
Energy Analysis of Main Propulsion Steam Turbine from Conventional LNG Carrier at Three Different Loads
}

\section{Energijska analiza glavne propulzijske parne turbine konvencionalnoga tankera za ukapljeni plin pri trima različitim opterećenjima}

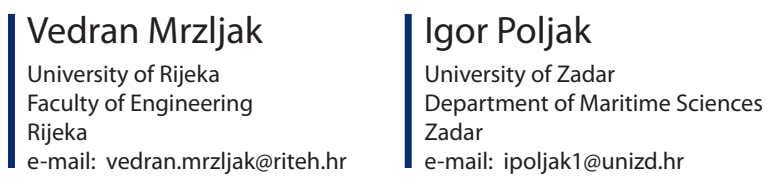

Summary

This paper presents energy analysis of entire marine main propulsion steam turbine and both of its cylinders at three different loads. Marine steam propulsion plant in which main turbine operates is described in detail. Measured data from real exploitation at each required turbine operating point enables calculation of energy losses and efficiencies. Real developed power distribution between both turbine cylinders is not the same at all observed loads. Energy losses and efficiencies of main turbine cylinders and entire main steam turbine increases during the increase in turbine load. An increase in turbine load resulted with in a sharp increase in energy efficiency of HPC (High Pressure Cylinder) from $\mathbf{5 1 . 0 1} \%$ to $\mathbf{7 4 . 1 3} \%$, while the increase in energy efficiency of LPC (Low Pressure Cylinder) is not as sharp (from $73.88 \%$ to $78.50 \%$ ). The change in energy efficiency of the entire main steam turbine during the load increase (from 65.54 $\%$ to $79.45 \%$ ) is mostly influenced by a change in energy efficiency of HPC. Energy loss and real developed power ratio is reversely proportional to energy efficiencies and losses of both steam turbine cylinders and the entire turbine.

\section{Sažetak}

Ovaj članak prikazuje energijsku analizu čitave glavne propulzijske parne turbine $i$ oba njezina kućišta pri trima različitim opterećenjima. Opisuje se podrobno, brodsko parno propulzijsko postrojenje u kojemu radi glavna turbina. Izmjereni podatci stvarne eksploatacije za svaku zahtijevanu radnu točka turbine omogućavaju izračun energijskih gubitaka i učinkovitosti. Stvaran raspored distribucije snage između oba kućišta turbine nije isti na svim promatranim opterećenjima. Energijski gubici i učinkovitosti turbinskih kućišta i cijele glavne turbine, povećavaju se za vrijeme porasta opterećenja turbine. Povećanje opterećenja turbine rezultira naglim rastom energijske učinkovitosti HPC (High Pressure Cylinder = kućište visokoga tlaka) od $51.01 \%$ do $74.13 \%$ dok povećanje energijske učinkovitosti LPC (Low Pressure Cylinder = kućište niskoga tlaka) nije tako naglo (od $73.88 \%$ do $78.50 \%$ ). Promjena energijske učinkovitosti cijele glavne parne turbine, za vrijeme povećanja opterećenja (od $65.54 \%$ do $79.45 \%$ ), najviše je pod utjecajem promjene energijske učinkovitosti HPC. Gubitak energije i stvarni omjer razvijene snage obrnuto je proporcionalan energijskim učinkovitostima igubicima za oba kućišta i cijelu parnu turbinu.
DOI 10.17818/NM/2019/1.2 UDK 621.165:629.5

Preliminary communication / Prethodno priopćenje Paper accepted / Rukopis primljen: 30. 10. 2018.

\section{KEY WORDS \\ main marine steam turbine marine propulsion plant energy analysis \\ change in load conditions}

\section{INTRODUCTION / Uvod}

Taking into account the entire world fleet, ship propulsion plants are today mainly based on diesel engines, regardless of its type and operation characteristics. Slow-speed two-stroke diesel engines are often used as main propulsion components [1], [2], while medium-speed or fast-speed four-stroke diesel engines in marine propulsion plants can be used in various combinations and variations [3].

Although slightly presented in the world fleet in general, steam propulsion is still the dominant propulsion plant for LNG
(Liquefied Natural Gas) carriers [4]. Specificity of LNG carrier operation and transported cargo were the main reason for steam propulsion usage, but nowadays also in this propulsion area impact of diesel engines increases more and more [5].

Likewise, new plants for the propulsion of LNG carriers are today under the development [6]. Greenhouse gas emissions reduction is the main and the most important goal for such new plants [7]. Proposed new plants for the propulsion of LNG carriers are very complex, so it is necessary to analyze the risk of its operations [8]. 
Such propulsion plants required power management systems [9] and multi-objective decision support systems [10]. Improvements on new LNG carriers do not include only the propulsion plant and its components it also includes optimal manipulation and management of transported cargo [11].

In this paper it is presented an energy analysis of main steam propulsion turbine from the conventional LNG carrier. Complete steam propulsion plant is described in which main steam turbine operates. Presented energy analysis includes entire main steam turbine and both of its cylinders (high pressure and low pressure cylinder). It was obtained a change in energy efficiencies and losses for main turbine and both turbine cylinders at three different loads. The presented analysis provides insight into the characteristics and processes of the main marine propulsion steam turbine at different operating regimes.

\section{DESCRIPTION AND OPERATING CHARACTERISTICS OF MARINE STEAM PROPULSION PLANT FROM CONVENTIONAL LNG CARRIER / Opis i radne osobine brodskog parnog propulzijskog postrojenja sa konvencionalnog tankera za prijevoz ukapljenog prirodnog plina}

Marine steam propulsion plant, in which analyzed main propulsion turbine operates, consists of two mirror-oriented parallel operating Steam Generators (SG), Fig. 1, to ensure safety plant operation even in case of any failure. Both steam generators have combined burners which can burn only one fuel (HFO or gas), or a combination of that two fuels [12]. Both steam generators produce a main steam flow stream (steam of the highest allowed temperature and pressure) which is led to main and auxiliary steam turbines and simultaneously auxiliary steam flow stream (steam with decreased temperature in comparison to the main steam stream) for additional heating purposes and for its usage in auxiliary ship systems [13]. One important steam plant component which uses auxiliary steam flow stream is Air Heater $(\mathrm{AH})$, which is used for increasing air temperature before its entrance in steam generators. Each steam generator has one steam air heater. Steam air heaters from marine steam power plants greatly differs from land-based steam power plant air heaters which are most often heated with flue gases [14], [15]. Flue gases in the marine steam generator exhaust do not have sufficient temperature for additional air heating.

The main steam flow stream produced in marine steam generators is delivered to all steam turbines (main and auxiliary turbines) which are mounted in the propulsion plant. Main propulsion turbine analyzed in this paper has two cylinders (HPC - High Pressure Cylinder and LPC - Low Pressure Cylinder) and is used for propulsion propeller drive, Fig. 1. Auxiliary steam turbines are Turbo-Generators (TG) and Main Feed water Pump Turbine (MFPT). Each marine steam propulsion plant has at least two parallel operating turbo-generators [16] which ensure the continuous production of electricity. Investigations of turbogenerators [17] and similar low power steam turbines [18] during the change in developed power showed that this kind of steam turbines reaches its highest efficiencies at approximately $70 \%-80 \%$ of maximum load. Main feed water pump turbine usually consists of one Curtis stage [19] and is used for Main Feed water Pump (MFP) drive.
Main marine condenser operation differs greatly when compared to steam condensers from land-based power plants [20]. At low propulsion plant loads, sea for marine condenser cooling is delivered by the pump, while at the high propulsion plant loads (at the satisfactory ship speed) sea water is delivered by the scoop (sea accumulation system). Condensate formed from steam is taken by the Condensate Extraction Pump (CEP) and delivered to deaerator through low pressure heating system. First component which provides condensate heating is Evaporator (EVAP) also called fresh water generator [21]. In marine low pressure condensate heating systems between evaporator and deaerator are usually located Sealing Steam Condenser (SSC) and one or more Low Pressure Heaters (LPH) [22]. Sealing steam condenser collects steam, which is omitted at outer labyrinth seals of all turbines installed in marine power plant [23] and uses that steam for condensate heating. From the viewpoint of condensate heating, low pressure heater and sealing steam condenser has an identical function with the difference that condensate heating is much more intensive in low pressure heater (or more of them). All the condensate from the plant which remains after heating processes is collected in the hot well [24] and pumped with Auxiliary Condensate Pump (ACP) to main condensate stream, Fig. 1.

Deaerator divides condensate/feed water heating system in low pressure and high pressure part [25]. In steam plants in general, not only the marine steam propulsion plant, deaerator has a dual function - first is direct condensate heating [26], while the second is the removal of dissolved gases from the condensate with the aim of pipeline corrosion reduction [27]. Between deaerator and steam generators in the marine steam propulsion plant is mounted Desuperheater (DES) and one or more High Pressure Heaters (HPH) [28]. Desuperheater is a heat exchanger used for steam preparation and delivering such prepared steam to all auxiliary marine systems [29].

In the marine propulsion plant can be found a number of pressure reduction valves [30] used for operating medium pressure reduction as well as regulation and control valves, Fig. 1. Improvement of marine steam propulsion plants can be done with steam re-heating process, what requires additional medium pressure turbine cylinder as a part of main turbine [31]. This improvement increases the complexity of steam propulsion plant, but also increases overall efficiency.

\section{ENERGY ANALYSIS OF MARINE MAIN PROPULSION STEAM TURBINE / Energijska analiza glavne brodske propulzijske parne turbine}

3.1. Energy analysis general equations for any control volume / Opće jednadžbe energijske analize za bilo koji kontrolni volumen

Energy conservation, defined by the first law of thermodynamics, is the baseline for energy analysis of any control volume [32], [33]. For control volume in steady state disregarding potential and kinetic energy, equations for the mass and energy balances can be defined according to [34] and [35] by using equations:

$$
\begin{aligned}
& \sum \dot{m}_{\text {in }}=\sum \dot{m}_{\text {out }} \\
& \dot{Q}-P=\sum \dot{m}_{\text {out }} \cdot h_{\text {out }}-\sum \dot{m}_{\text {in }} \cdot h_{\text {in }}
\end{aligned}
$$

The total flow energy can be defined according to [36] by the equation: 


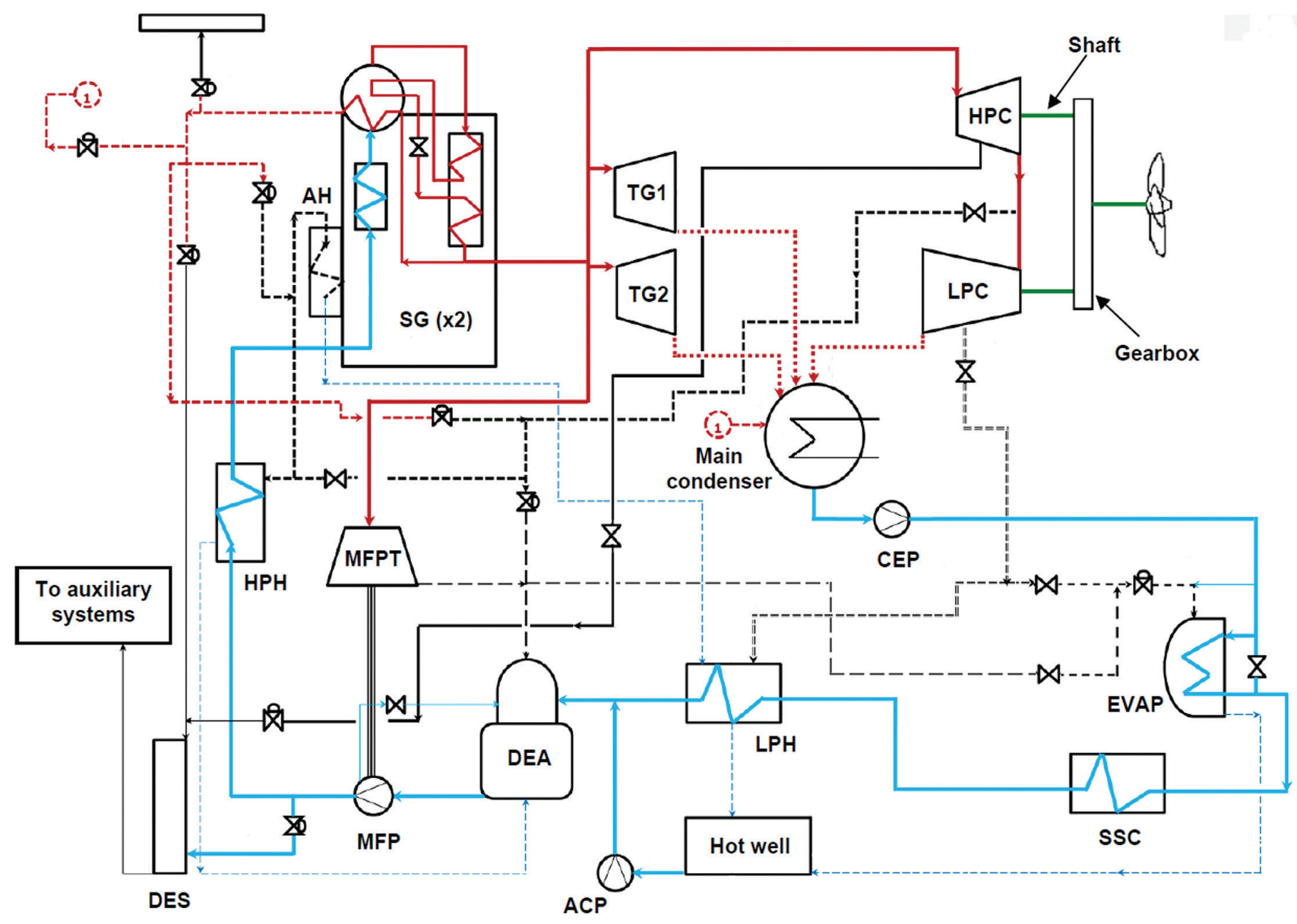

Figure 1 General scheme of marine steam propulsion plant from the conventional LNG carrier (SG = Steam Generator; $\mathrm{AH}=$ Air Heater; TG = Turbo-Generator; HPC = High Pressure Cylinder; LPC = Low Pressure Cylinder; CEP = Condensate Extraction

Pump; EVAP = Evaporator; SSC = Sealing Steam Condenser (Gland steam condenser); LPH = Low Pressure Heater; ACP = Auxiliary Condensate Pump; DEA = Deaerator; MFP = Main Feed-water Pump; MFPT = Main Feed-water Pump Turbine; DES = Desuperheater; $\mathrm{HPH}=$ High Pressure Heater)

Slika 1. Opća shema brodskog parnog postrojenja za konvencionalni brod za prijevoz ukapljenoga plina (SG = generator pare; $A H=$ grijač zraka; TG = turbo-generator; $H P C=$ kućište visokoga tlaka; $L P C=$ kućište niskoga tlaka; $C E P=$ ekstrakcijska pumpa kondenzata;

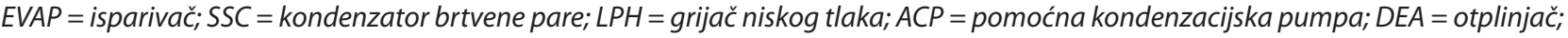
$M F P=$ glavna pumpa napojne vode; $M F P T$ = turbina za pogon glavne pumpe napojne vode; DES = uređaj za pripremu pomoćne pare; $\mathrm{HPH}=$ grijač visokoga tlaka)

$\dot{E}_{\text {en }}=\dot{m} \cdot h$

A type and characteristics of any control volume define its energy efficiency. Therefore, energy efficiency in general can take different forms [37], [38]. In the most of the cases, energy efficiency can be defined as:

$$
\eta_{\text {en }}=\frac{\text { Energy output }}{\text { Energy input }}
$$

These governing equations are used in energy analysis of entire main propulsion steam turbine and both of its cylinders.

\subsection{Equations and principles of marine main propulsion steam turbine energy analysis / Jednadžbe i principi energijske analize glavne brodske parne propulzijske turbine}

As presented in Fig. 1, the main propulsion steam turbine has two cylinders - High Pressure Cylinder (HPC) and Low Pressure Cylinder (LPC). HPC has eight turbine stages (first regulation stage is Curtis stage and seven Rateau stages) and the LPC has ten stages (two Curtis stages for astern drive and eight Rateau stages for driving ahead). The main propulsion turbine has three steam subtractions, Fig. 2. First subtraction is from HPC, second subtraction is positioned between HPC and LPC, while the third subtraction is from LPC [39].

In Fig. 2 there are also presented steam stream flow marks required for proper main turbine energy analysis. Streams were marked with letters from A to G. According to Fig. 1, on Fig. 2 it was noted each steam flow and components from which steam enters into the main turbine or to which the steam is supplied from the main turbine. Steam mass flow through each steam subtraction is dependable on the current propulsion plant load. Both main turbine cylinders were connected to the propulsion propeller by using gearbox, Fig. 2 . 


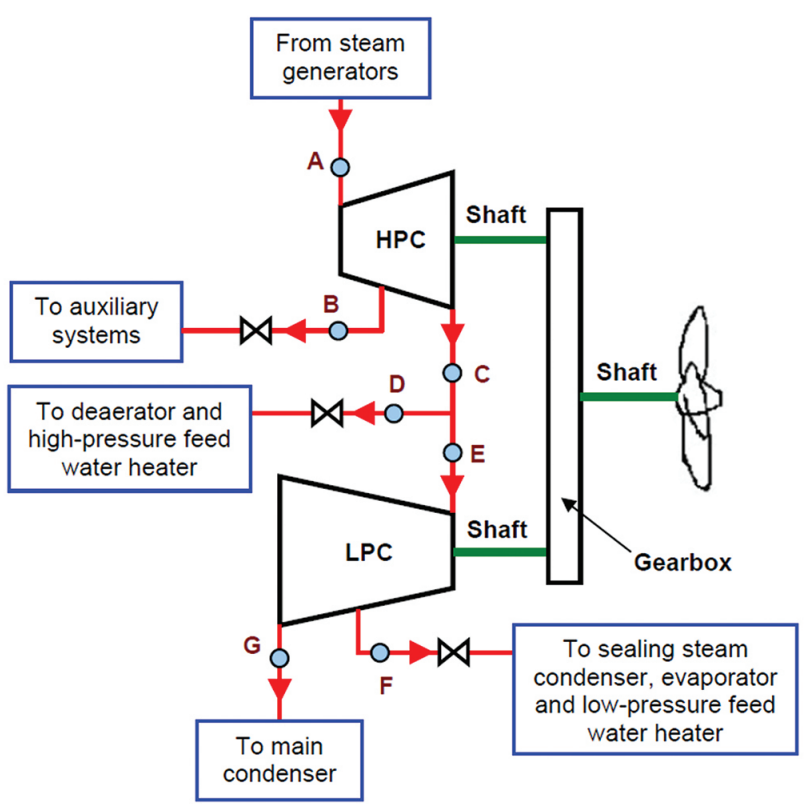

Figure 2 Analyzed main propulsion steam turbine with marked operating points

Slika 2. Analizirana glavna propulzijska parna turbina s označenim radnim točkama

Steam stream flow marks (operating points) presented in Fig. 2 defines real (polytropic) expansion in the main propulsion turbine and both of its cylinders. The real steam expansion process is presented in $h$-s diagram, Fig. 3 , with a green curve by using operating points from Fig. 2. Steam mass flows subtracted from the main turbine are marked with red arrows. The end of steam expansion in the main propulsion turbine is under the saturation line (point G, Fig. 2 and Fig. 3), all the other operating points are in the superheated steam area at each observed turbine load. A steam mass flow, which is lost on the turbine outer labyrinth seals [40] was neglected.

Main steam turbine energy analysis, as well as energy analysis of both of its cylinders, is based on comparison of real (polytropic) and ideal (isentropic) steam expansion processes. Ideal (isentropic) steam expansion process assumes always the same steam specific entropy. In $h$-s diagram, Fig. 3, real steam expansion at main turbine HPC is marked with points $A-B-C$, while the ideal expansion process is marked with points $A-B_{2}-C_{2}$. At main turbine LPC real steam expansion represents points $\mathrm{E}-\mathrm{F}-\mathrm{G}$ and ideal expansion is marked with points $\mathrm{E}-\mathrm{F}_{1}-\mathrm{G}_{1}$. The entire main propulsion turbine has real expansion process defined with points A-B-C-F-G, while the ideal expansion process for the entire main turbine is marked with points $A-B_{2}-$ $C_{2}-F_{2}-G_{2}$. To obtain a proper energy analysis of each main turbine cylinder, isentropic steam expansions must begin at the point of steam entrance in each cylinder, as presented in Fig. 3, due to the isobars propagation during the increase in steam specific entropy.

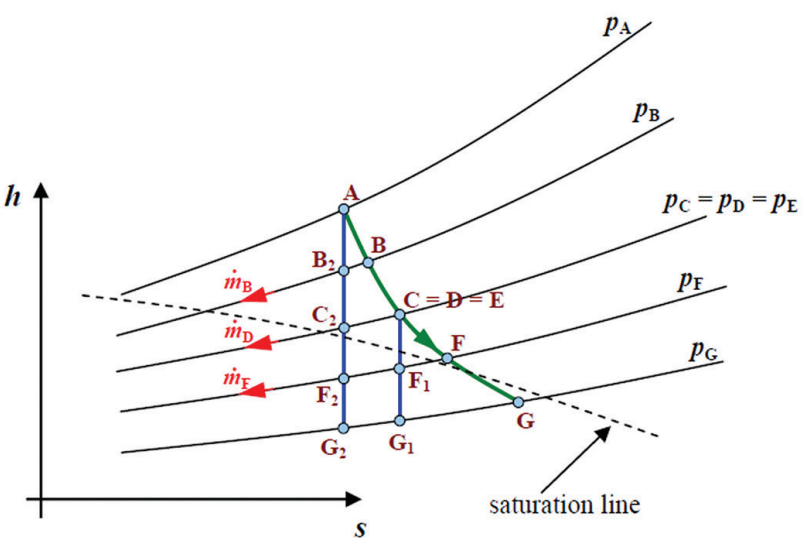

Figure 3 Real (polytropic) and ideal (isentropic) steam expansions in $h$-s diagram for the entire marine steam turbine and both of its cylinders

Slika 3. Stvarna (politropska) i idealna (izenotropska) ekspanzija u h-s dijagramu za cijelu brodsku parnu turbinu i oba njezina kućišta

Energy analysis equations for the entire marine steam turbine and both of its cylinders are obtained by using operating points from Fig. 2 and steam real/ideal expansion processes presented in Fig. 3.

3.2.1. Energy analysis of main propulsion steam turbine cylinders / Energijska analiza kućišta glavne propulzijske parne turbine

High Pressure Cylinder (HPC) / Kućište visokoga tlaka

- Mass flow balance:

$\dot{m}_{\mathrm{A}}=\dot{m}_{\mathrm{B}}+\dot{m}_{\mathrm{C}}$

- HPC real (polytropic) power:

$P_{\mathrm{HPC}, \mathrm{PT}}=\dot{m}_{\mathrm{A}} \cdot\left(h_{\mathrm{A}}-h_{\mathrm{B}}\right)+\dot{m}_{\mathrm{C}} \cdot\left(h_{\mathrm{B}}-h_{\mathrm{C}}\right)$

- HPC ideal (isentropic) power:

$P_{\mathrm{HPC}, \mathrm{IS}}=\dot{m}_{\mathrm{A}} \cdot\left(h_{\mathrm{A}}-h_{\mathrm{B}_{2}}\right)+\dot{m}_{\mathrm{C}} \cdot\left(h_{\mathrm{B}_{2}}-h_{\mathrm{C}_{2}}\right)$

- HPC energy loss:

$\dot{E}_{\mathrm{en}, \mathrm{HPC}, \text { loss }}=P_{\mathrm{HPC}, \mathrm{IS}}-P_{\mathrm{HPC}, \mathrm{PT}}=\dot{m}_{\mathrm{B}} \cdot\left(h_{\mathrm{B}}-h_{\mathrm{B}_{2}}\right)+\dot{m}_{\mathrm{C}} \cdot\left(h_{\mathrm{C}}-h_{\mathrm{C}_{2}}\right)$

HPC energy efficiency:

$\eta_{\text {en, HPC }}=\frac{P_{\mathrm{HPC}, \mathrm{PT}}}{P_{\mathrm{HPC}, \mathrm{IS}}}=\frac{\dot{m}_{\mathrm{A}} \cdot\left(h_{\mathrm{A}}-h_{\mathrm{B}}\right)+\dot{m}_{\mathrm{C}} \cdot\left(h_{\mathrm{B}}-h_{\mathrm{C}}\right)}{\dot{m}_{\mathrm{A}} \cdot\left(h_{\mathrm{A}}-h_{\mathrm{B}_{2}}\right)+\dot{m}_{\mathrm{C}} \cdot\left(h_{\mathrm{B}_{2}}-h_{\mathrm{C}_{2}}\right)}$

- HPC energy power loss and real developed power ratio:

$R_{\mathrm{HPC}}=\frac{\dot{E}_{\mathrm{en}, \mathrm{HPC}, \text { loss }}}{P_{\mathrm{HPC}, \mathrm{PT}}}$

Low Pressure Cylinder (LPC) / Kućište niskoga tlaka

- Mass flow balance:

$\dot{m}_{\mathrm{E}}=\dot{m}_{\mathrm{F}}+\dot{m}_{\mathrm{G}}$

- LPC real (polytropic) power:

$P_{\mathrm{LPC}, \mathrm{PT}}=\dot{m}_{\mathrm{E}} \cdot\left(h_{\mathrm{E}}-h_{\mathrm{F}}\right)+\dot{m}_{\mathrm{G}} \cdot\left(h_{\mathrm{F}}-h_{\mathrm{G}}\right)$

- LPC ideal (isentropic) power:

$P_{\mathrm{LPC}, \mathrm{IS}}=\dot{m}_{\mathrm{E}} \cdot\left(h_{\mathrm{E}}-h_{\mathrm{F}_{1}}\right)+\dot{m}_{\mathrm{G}} \cdot\left(h_{\mathrm{F}_{1}}-h_{\mathrm{G}_{1}}\right)$

- LPC energy loss:

$\dot{E}_{\text {en, LPC, loss }}=P_{\mathrm{LPC}, \mathrm{IS}}-P_{\mathrm{LPC}, \mathrm{PT}}=\dot{m}_{\mathrm{F}} \cdot\left(h_{\mathrm{F}}-h_{\mathrm{F}_{1}}\right)+\dot{m}_{\mathrm{G}} \cdot\left(h_{\mathrm{G}}-h_{\mathrm{G}_{1}}\right)$

- LPC energy efficiency:

$\eta_{\text {en,LPC }}=\frac{P_{\mathrm{LPC}, \mathrm{PT}}}{P_{\mathrm{LPC}, \mathrm{IS}}}=\frac{\dot{m}_{\mathrm{E}} \cdot\left(h_{\mathrm{E}}-h_{\mathrm{F}}\right)+\dot{m}_{\mathrm{G}} \cdot\left(h_{\mathrm{F}}-h_{\mathrm{G}}\right)}{\dot{m}_{\mathrm{E}} \cdot\left(h_{\mathrm{E}}-h_{\mathrm{F}_{1}}\right)+\dot{m}_{\mathrm{G}} \cdot\left(h_{\mathrm{F}_{\mathrm{F}}}-h_{\mathrm{G}_{\mathrm{l}}}\right)}$

- LPC energy power loss and real developed power ratio:

$R_{\mathrm{LPC}}=\frac{\dot{E}_{\text {en }, \mathrm{LPC}, \text { loss }}}{P_{\mathrm{LPC}, \mathrm{PT}}}$ 
3.2.2. Energy analysis of the entire main propulsion steam turbine / Energijska analiza čitave glavne propulzijske parne turbine

- Mass flow balance:

$\dot{m}_{\mathrm{A}}=\dot{m}_{\mathrm{B}}+\dot{m}_{\mathrm{D}}+\dot{m}_{\mathrm{F}}+\dot{m}_{\mathrm{G}}$

- Main turbine real (polytropic) power:

$P_{\mathrm{MT}, \mathrm{PT}}=\dot{m}_{\mathrm{A}} \cdot\left(h_{\mathrm{A}}-h_{\mathrm{B}}\right)+\dot{m}_{\mathrm{C}} \cdot\left(h_{\mathrm{B}}-h_{\mathrm{C}}\right)+\dot{m}_{\mathrm{E}} \cdot\left(h_{\mathrm{E}}-h_{\mathrm{F}}\right)+\dot{m}_{\mathrm{G}} \cdot\left(h_{\mathrm{F}}-h_{\mathrm{G}}\right)(18)$

- Main turbine ideal (isentropic) power:

$P_{\mathrm{MT}, \mathrm{IS}}=\dot{m}_{\mathrm{A}} \cdot\left(h_{\mathrm{A}}-h_{\mathrm{B}_{2}}\right)+\dot{m}_{\mathrm{C}} \cdot\left(h_{\mathrm{B}_{2}}-h_{\mathrm{C}_{2}}\right)+\dot{m}_{\mathrm{E}} \cdot\left(h_{\mathrm{C}_{2}}-h_{\mathrm{F}_{2}}\right)+\dot{m}_{\mathrm{G}} \cdot\left(h_{\mathrm{F}_{2}}-h_{\mathrm{G}_{2}}\right)(19)$

- Main turbine energy loss:

$\dot{E}_{\mathrm{en}, \mathrm{MT}, \text { loss }}=P_{\mathrm{MT}, \mathrm{IS}}-P_{\mathrm{MT}, \mathrm{PT}}=\dot{m}_{\mathrm{B}} \cdot\left(h_{\mathrm{B}}-h_{\mathrm{B}_{2}}\right)+\dot{m}_{\mathrm{D}} \cdot\left(h_{\mathrm{C}}-h_{\mathrm{C}_{2}}\right)+\dot{m}_{\mathrm{F}} \cdot\left(h_{\mathrm{F}}-h_{\mathrm{F}_{2}}\right)+\dot{m}_{\mathrm{G}} \cdot\left(h_{\mathrm{G}}-h_{\mathrm{G}_{2}}\right)(20)$

- Main turbine energy efficiency:

$\eta_{\mathrm{cn}, \mathrm{MT}}=\frac{P_{\mathrm{MT}, \mathrm{PT}}}{P_{\mathrm{MT}, \mathrm{IS}}}=\frac{\dot{m}_{\mathrm{A}} \cdot\left(h_{\mathrm{A}}-h_{\mathrm{B}}\right)+\dot{m}_{\mathrm{C}} \cdot\left(h_{\mathrm{B}}-h_{\mathrm{C}}\right)+\dot{m}_{\mathrm{E}} \cdot\left(h_{\mathrm{E}}-h_{\mathrm{F}}\right)+\dot{m}_{\mathrm{G}} \cdot\left(h_{\mathrm{F}}-h_{\mathrm{G}}\right)}{\dot{m}_{\mathrm{A}} \cdot\left(h_{\mathrm{A}}-h_{\mathrm{B}_{2}}\right)+\dot{m}_{\mathrm{C}} \cdot\left(h_{\mathrm{B}_{2}}-h_{\mathrm{C}_{2}}\right)+\dot{m}_{\mathrm{E}} \cdot\left(h_{\mathrm{C}_{2}}-h_{\mathrm{F}_{2}}\right)+\dot{m}_{\mathrm{G}} \cdot\left(h_{\mathrm{F}_{2}}-h_{\mathrm{G}_{2}}\right)}(21)$

- Main turbine energy power loss and real developed power ratio:

$R_{\mathrm{MT}}=\frac{\dot{E}_{\mathrm{en}, \mathrm{MT}, \text { loss }}}{P_{\mathrm{MT}, \mathrm{PT}}}$

Steam specific enthalpies (h) and steam specific entropies (s) of the main propulsion turbine and both of its cylinders are calculated from measured steam temperatures and pressures at each operating point, Fig. 2, by using NIST REFPROP 9.0 software [41]. It was taken into account that steam specific entropy (s) is always the same for each operating point at any isentropic expansion, Fig. 3.

7) 4. MEASUREMENT RESULTS OF ANALYZED MARINE MAIN PROPULSION STEAM TURBINE / Rezultati mjerenja analizirane brodske glavne propulzijske parne turbine

For energy analysis of marine main propulsion steam turbine required operating parameters are steam temperatures, steam pressures and steam mass flows at each turbine operating point from Fig. 2. According to producer specifications, maximum main steam turbine power is equal to $29420 \mathrm{~kW}$ [39]. Operating parameters were measured at each of three observed turbine loads during LNG carrier exploitation: low load $(13.5 \%$ of maximum turbine power), middle load ( $62 \%$ of maximum turbine power) and high load ( $84.4 \%$ of maximum turbine power).

Table 1 presented measurement results for all required main turbine operating points at low turbine load with a note that steam specific enthalpy in each operating point was calculated by

Table 1 Main propulsion turbine - measured operating parameters at low turbine load Tablica 1. Glavna propulzijska turbina - izmjereni radni parametri pri niskom opterećenju turbine

\begin{tabular}{|c|c|c|c|c|}
\hline \multicolumn{5}{|c|}{ LOW LOAD $(13.5 \%$ of maximum turbine power) } \\
\hline Operating point* & Temperature $\left({ }^{\circ} \mathrm{C}\right)$ & Pressure $(\mathrm{MPa})$ & Mass flow $(\mathrm{kg} / \mathrm{h})$ & Specific enthalpy $(\mathrm{kJ} / \mathrm{kg})$ \\
\hline A & 488.0 & 6.19 & 16605 & 3392.2 \\
\hline B & - & - & 0 & - \\
\hline C & 243.0 & 0.151 & 16605 & 2958.8 \\
\hline D & - & - & 0 & - \\
\hline E & 243.0 & 0.151 & 16605 & 2958.8 \\
\hline F & - & - & 0 & - \\
\hline G & 32.5 & 0.00489 & 16605 & 2531.7 \\
\hline
\end{tabular}

* Operating points refer to Fig. 2 .

Table 2 Main propulsion turbine - measured operating parameters at middle turbine load Tablica 2. Glavna propulzijska turbina - izmjereni radni parametri kod srednjega opterećenja turbine

\begin{tabular}{|c|c|c|c|c|}
\hline \multicolumn{5}{|c|}{ MIDDLE LOAD (62 \% of maximum turbine power) } \\
\hline Operating point & Temperature $\left({ }^{\circ} \mathrm{C}\right)$ & Pressure $(\mathrm{MPa})$ & Mass flow $(\mathrm{kg} / \mathrm{h})$ & Specific enthalpy $(\mathrm{kJ} / \mathrm{kg})$ \\
\hline A & 513.5 & 6.02 & 65012 & 3454.9 \\
\hline B & - & - & 0 & - \\
\hline C & 256.0 & 0.467 & 65012 & 2974.6 \\
\hline D & 256.0 & 0.467 & 4690 & 2974.6 \\
\hline E & 256.0 & 0.467 & 60322 & 2974.6 \\
\hline F & 156.0 & 0.097 & 2032 & 2788.7 \\
\hline G & 29.5 & 0.00412 & 58290 & 2390.0 \\
\hline
\end{tabular}

* Operating points refer to Fig. 2 .

Table 3 Main propulsion turbine - measured operating parameters at high turbine load Tablica 3. Glavna propulzijska turbina - izmjereni radni parametri pri visokom opterećenju turbine

\begin{tabular}{|c|c|c|c|c|}
\hline \multicolumn{5}{|c|}{ HIGH LOAD $(84.4 \%$ of maximum turbine power) } \\
\hline Operating point* & Temperature $\left({ }^{\circ} \mathrm{C}\right)$ & Pressure $(\mathrm{MPa})$ & Mass flow $(\mathrm{kg} / \mathrm{h})$ & Specific enthalpy $(\mathrm{kJ} / \mathrm{kg})$ \\
\hline A & 500.0 & 5.899 & 96474 & 3424.3 \\
\hline B & 350.0 & 1.565 & 3268 & 3146.7 \\
\hline C & 256.0 & 0.593 & 93206 & 2970.4 \\
\hline D & 256.0 & 0.593 & 13609 & 2970.4 \\
\hline E & 256.0 & 0.593 & 79597 & 2970.4 \\
\hline F & 153.0 & 0.121 & 3355 & 2781.1 \\
\hline G & 34.9 & 0.00561 & 76242 & 2373.4 \\
\hline
\end{tabular}

* Operating points refer to Fig. 2 . 
Table 4 Measuring equipment of the main propulsion turbine Tablica 4. Mjerna oprema glavne propulzijske turbine

Steam pressure measuring equipment

Steam temperature measuring equipment

Steam mass flow measuring equipment
Yamatake JTG960A and Yamatake JTG940A pressure transmitters [42]

Greisinger GTF 601-Pt100 and Greisinger GTF 401-Pt100 immersion probes [43]

Yamatake JTD960A, Yamatake JTD930A, Yamatake JTD920A and Yamatake JTD910A differential pressure transmitters [44] using NIST REFPROP 9.0 software [41]. From Table 1 can be seen that all of three main turbine subtractions are closed at low load. Some components from steam propulsion plant requires steam for heating even at a low load - at low load that components get a steam from auxiliary steam generators stream flow.

Table 2 presents measurement results for all required main turbine operating points at middle turbine load. Again, steam specific enthalpies were not measured - they were calculated by using steam temperature and pressure in each operating point. At middle main turbine load first steam subtraction is still closed (operating point B, Fig. 2), while second and third steam subtractions (operating points D and F, Fig. 2) are open at this load and some steam plant components gets a superheated steam direct from the main turbine.

Measurement results for all main turbine operating points at high turbine load are presented in Table 3 along with calculated steam specific enthalpies. At high turbine load all the steam subtractions are opened and in such operation regime all steam propulsion plant components get a heating steam from the main turbine. Auxiliary systems also get a steam from the main turbine, which means that auxiliary steam flow from steam generators in this operation regime is almost equal to zero [13].

In the LNG carrier propulsion plant, measuring equipment is already mounted at all inlets and outlets of both main turbine cylinders and between two cylinders (second steam subtraction), Fig. 2. That equipment is used for control and regulation of the main propulsion turbine, its subtractions and each cylinder individually. Measuring equipment is listed in Table 4.

\section{THE RESULTS OF ENERGY ANALYSIS OF MARINE MAIN PROPULSION STEAM TURBINE AND DISCUSSION / Rezultati energijske analize brodske glavne propulzijske parne turbine i rasprava}

The change in real (polytropic) and ideal (isentropic) developed power for both turbine cylinders of the analyzed main propulsion turbine at three observed loads are presented in Fig. 4.

At low main turbine load, real produced power by HPC is slightly higher when compared to LPC (1999 kW for HPC and $1970 \mathrm{~kW}$ for LPC). Increase in main turbine load resulted with a change in real produced power distribution between turbine

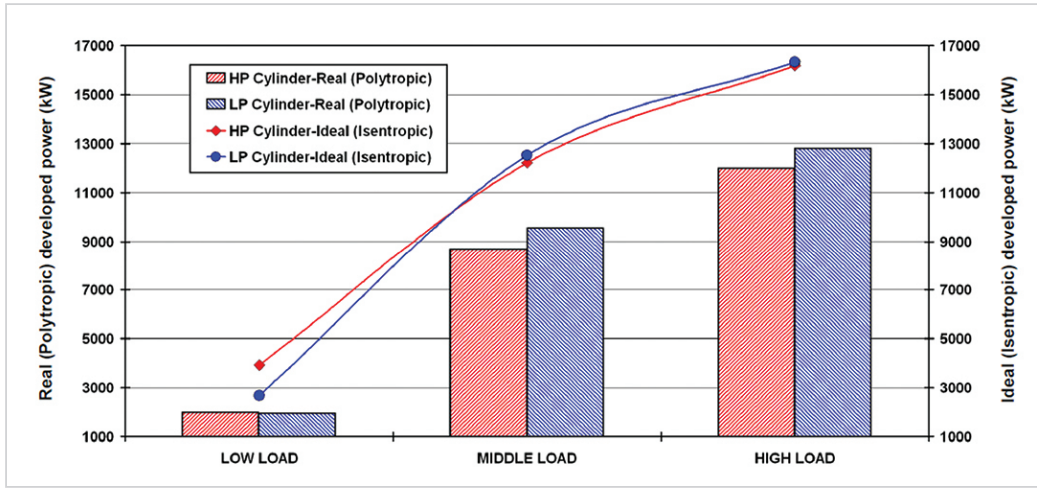

Figure 4 Change in real and ideal developed power for both turbine cylinders at three observed loads Slika 4. Promjena u stvarnoj i idealnoj snazi za oba turbinska kućišta kod triju promatranih opterećenja

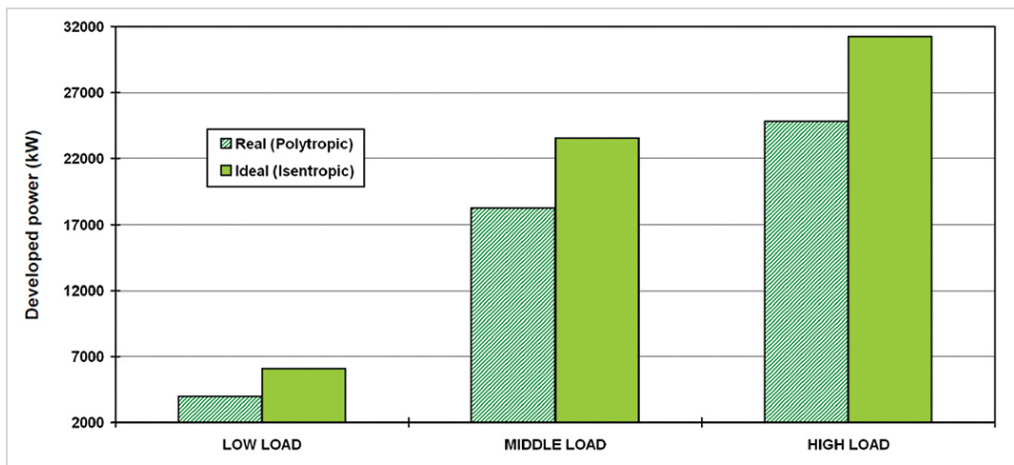

Figure 5 Change in real and ideal developed power for the entire main steam turbine at three observed loads Slika 5. Promjena u stvarnoj i idealnoj snazi za cijelu glavnu parnu turbinu pri trima promatranim opterećenjima 
cylinders. At the middle and high main turbine loads LPC produces higher real power in comparison with HPC (at middle load LPC produces $9570.58 \mathrm{~kW}$, while HPC produces $8773.68 \mathrm{~kW}$ of real power and at high load real power distribution is $12819.88 \mathrm{~kW}$ for LPC and 12003.72 kW for HPC).

For each turbine cylinder or for the entire main turbine, ideal (isentropic) power must be higher than the real one, because isentropic power is the theoretical one and assumes an ideal expansion process (always the same steam specific entropy). Fig. 4 presented that at low main turbine load HPC has much more potential in comparison with LPC and can develop higher theoretical (isentropic) power. At the middle and high main turbine loads, ideal (isentropic) power which can be produced by turbine cylinders in ideal situation is slightly higher for LPC.

For the entire main marine steam turbine at three observed loads change in real and ideal developed power is presented in Fig. 5. At low turbine load real developed power of the entire main turbine is equal to $3969 \mathrm{~kW}$, while ideal power which can theoretically be developed at low turbine load is $6056.21 \mathrm{~kW}$. Increase in main turbine load resulted with continuous increase in real and ideal main turbine power. At middle turbine load ideal (isentropic) power of the entire main turbine is equal to 23543.34 $\mathrm{kW}$, while at a high load ideal power of the entire main turbine is $31246.12 \mathrm{~kW}$. Improvement potential of steam expansion process at the main marine propulsion turbine cannot be neglected because real developed power of the entire main turbine at middle and high loads is equal to $18244.26 \mathrm{~kW}$ and $24823.6 \mathrm{~kW}$.

Energy power losses of each main propulsion turbine cylinder increase during the increase in turbine load, Fig. 6 . Also at each observed load, energy losses of HPC are higher when compared to LPC. From the lowest to the highest observed main turbine load energy losses of HPC is equal to $1920.18 \mathrm{~kW}, 3537.74 \mathrm{~kW}$ and $4188.93 \mathrm{~kW}$, while energy losses of LPC for the same load range is $696.49 \mathrm{~kW}, 2963.53 \mathrm{~kW}$ and $3510.5 \mathrm{~kW}$. The difference in energy losses between main turbine HPC and LPC is the highest at turbine low load and is equal to $1223.7 \mathrm{~kW}$, while at middle and high turbine loads that difference amounts $574.2 \mathrm{~kW}$ and $678.43 \mathrm{~kW}$.

The energy efficiency of both main turbine cylinders increases during the increase in turbine load, Fig. 6. Energy efficiency of LPC is higher in comparison with HPC at each observed main turbine load. It should be noted that an increase in energy efficiency during the increase in main turbine load is much sharper for HPC than for LPC. Increase in main turbine load resulted with an increase of HPC energy efficiency from $51.01 \%$ (low load) up to $74.13 \%$ (high load), while in the same load range energy efficiency of LPC increases from $73.88 \%$ (low load) to $78.50 \%$ (high load).

As for the majority of steam power plant components [37], for the entire main marine propulsion turbine energy losses also show a trend of continuous increase during the increase in turbine load, Fig. 7. For the entire main propulsion turbine energy loss at low load is equal to $2087.16 \mathrm{~kW}$, at middle load $5299.07 \mathrm{~kW}$ and at high load $6422.52 \mathrm{~kW}$.

Energy efficiency of entire main propulsion turbine sharply increases during the increase in turbine load, Fig. 7. At low turbine load energy efficiency of entire turbine is $65.54 \%$ and then increases to $77.49 \%$ at middle load and to $79.45 \%$ at high load. When compared Fig. 6 and Fig. 7 it can clearly be seen that the curve of entire turbine energy efficiency change during the change

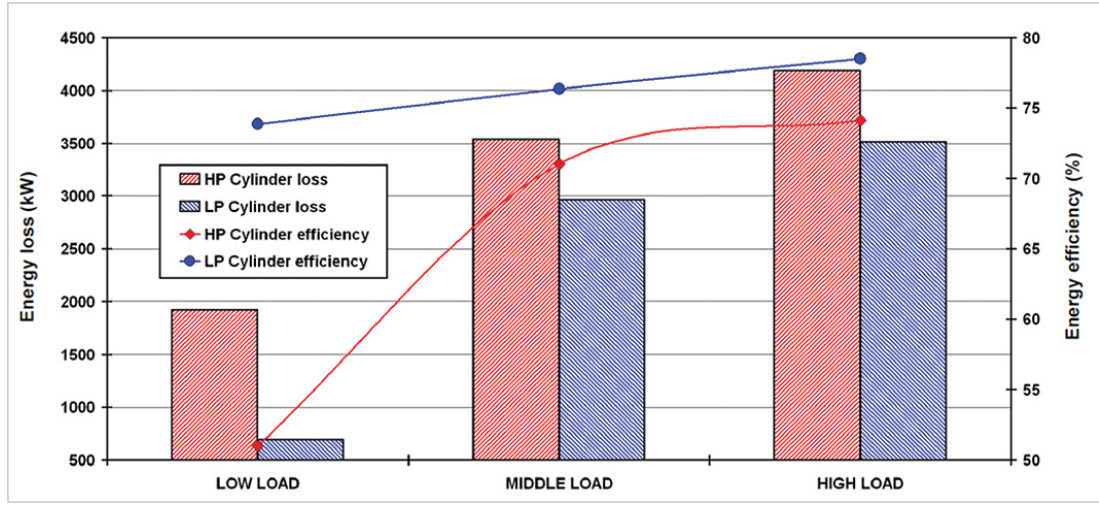

Figure 6 Change in energy losses and efficiencies for both turbine cylinders at three observed loads Slika 6. Promjena energijskih gubitaka i učinkovitosti za oba turbinska kućišta pri trima promatranim opterećenjima

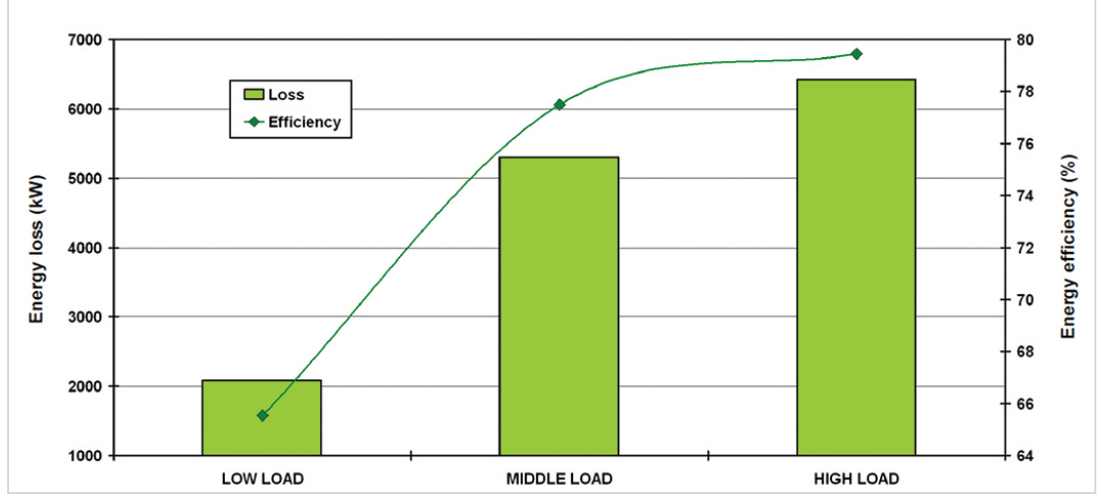

Figure 7 Change in energy losses and efficiencies for the entire main turbine at three observed loads Slika 7. Promjena energijskih gubitaka i učinkovitosti za cijelu glavnu turbinu kod triju promatranih opterećenja 


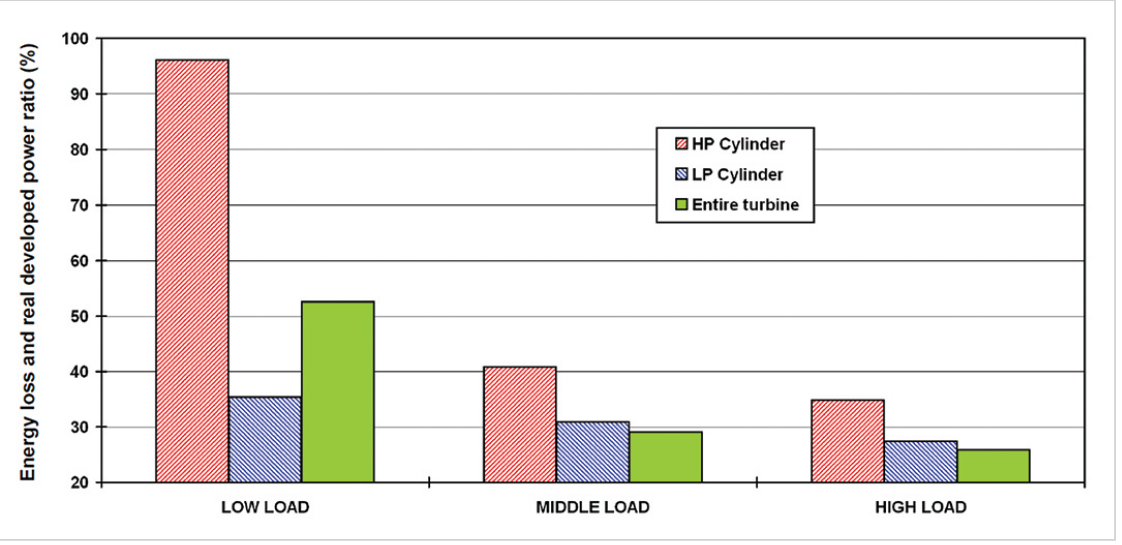

Figure 8 Energy loss and real developed power ratio for both turbine cylinders and the entire turbine at three observed loads Slika 8. Energijski gubici i omjer stvarno razvijene snage za oba turbinska kućišta i za cijelu turbinu kod triju promatranih opterećenja

in turbine load has the same shape as the curve of HPC energy efficiency change. This comparison leads to the conclusion that the change in energy efficiency of the entire marine propulsion turbine is mostly influenced by a change in energy efficiency of HPC.

Energy loss and real developed power ratio for both turbine cylinders and the entire turbine at three observed loads is presented in Fig. 8. This ratio is reversed proportional to energy efficiencies and energy losses for the entire main propulsion turbine and both of its cylinders. From Fig. 8 is visible that energy loss and real power ratio at low load is the highest for HPC and significantly decreases during the increase in HPC (and simultaneously entire main turbine) load. Energy loss and real power ratio has the smallest change during the increase in turbine load for LPC. Therefore, it can be concluded that the change in energy loss and real power ratio during the load increase for the entire main turbine is the most influenced by change of the same ratio for HPC.

At low main turbine load energy loss and real power ratio of HPC is equal to $96.05 \%$ and for the entire turbine that ratio at low load is $52.59 \%$, Fig. 8. Such ratios at low load for HPC and entire main turbine resulted with low energy efficiency (51.01\% for HPC and $65.54 \%$ for entire turbine), Fig. 6 and Fig. 7. Energy loss and real power ratio of $L P C$ at low turbine load is equal to $35.35 \%$, which as a result gives high LPC energy efficiency (73.88\%), Fig. 6. An increase in turbine load leads to decrease in energy loss and real power ratio of the entire main turbine and both of its cylinders, what resulted in a significant increase in energy efficiency.

\section{CONCLUSIONS / Zaključci}

In this paper it is presented an energy analysis of entire marine main turbine and both of its cylinders at three different turbine loads. It is presented and described the marine steam propulsion plant in which main turbine operates. Based on the measured data from real exploitation it was obtained specific enthalpies at each required turbine operating point as essential elements for turbine energy analysis. Main turbine energy analysis is based on a comparison of real (polytropic) steam expansion process throughout turbine with ideal (isentropic) steam expansion process which always assumes the same steam specific entropy. It was also investigated the influences of each main turbine cylinder on the operation of the entire main turbine. The most important conclusions of the presented analysis are:

- Real developed power distribution between both turbine cylinders is not the same at all observed loads. At low turbine load HPC produces slightly higher real power in comparison with LPC, while at middle and high turbine loads real power production is opposite (LPC produces higher real power then $\mathrm{HPC})$.

Energy losses of both main turbine cylinders increase during the increase in turbine load. For HPC that increase is from 1920.18 $\mathrm{kW}$ up to $4188.93 \mathrm{~kW}$, while for LPC that increase is from 696.49 $\mathrm{kW}$ up to $3510.50 \mathrm{~kW}$. At each observed load, energy loss of HPC is higher when compared to LPC.

Energy efficiencies of both main turbine cylinders increase during the increase in turbine load. Increase in energy efficiency during the increase in main turbine load is much sharper for HPC than for LPC (from $51.01 \%$ up to $74.13 \%$ for HPC and from $73.88 \%$ to $78.50 \%$ for LPC). At each observed load, energy efficiency of LPC is higher when compared to HPC.

- As for both main turbine cylinders also for the entire main turbine energy losses increases during the increase in turbine load (from $2087.16 \mathrm{~kW}$ to $6422.52 \mathrm{~kW}$ ).

- Energy efficiency of entire main propulsion turbine sharply increases during the increase in turbine load from $65.54 \%$ to $79.45 \%$. The change in energy efficiency of the entire main propulsion turbine is mostly influenced by a change in energy efficiency of HPC.

- Energy loss and real developed power ratio for both turbine cylinders and the entire turbine is reversed proportional to energy efficiencies and energy losses. The high value of energy loss and real developed power ratio resulted with low energy efficiency of entire main turbine or each of its cylinders and vice versa.

This analysis can be helpful to engineers and crew of marine steam propulsion plants in order to optimize operation of main propulsion turbine or each of its cylinders, as well as the entire marine steam power plant. Further research of main marine propulsion turbine will be based on steam subtractions optimization with a goal to reduce fuel consumption in steam generators and, if possible, increase marine steam propulsion plant overall efficiency.

\section{ACKNOWLEDGMENT / Zahvala}

The authors would like to extend their appreciations to the main ship-owner office for conceding measuring equipment and for all help during the exploitation measurements. This work has been fully supported by the Croatian Science Foundation under the project IP-2018-01-3739. 


\section{NOMENCLATURE / Nazivlje \\ Abbreviations:}

HPC High Pressure Cylinder

LPC Low Pressure Cylinder

\section{Latin Symbols:}

$\dot{E} \quad$ the total energy of a flow, kW

$h$ specific enthalpy, $\mathrm{kJ} / \mathrm{kg}$

$\dot{m} \quad$ mass flow rate, $\mathrm{kg} / \mathrm{s}$ (or kg/h)

$p \quad$ pressure, $\mathrm{MPa}$

$P \quad$ power, $\mathrm{kW}$

$\dot{Q} \quad$ heat transfer, $\mathrm{kW}$

$S \quad$ specific entropy, $\mathrm{kJ} / \mathrm{kg} \cdot \mathrm{K}$

$T \quad$ temperature, ${ }^{\circ} \mathrm{C}$

Greek symbols:

$\eta \quad$ efficiency, \%

\section{Subscripts:}

en energy

in inlet (input)

IS isentropic (ideal steam expansion)

MT main turbine

out outlet (output)

PT polytropic (real steam expansion)

$\mathrm{R} \quad$ energy power loss and real power ratio

\section{REFERENCES / Literatura}

[1] Mrzljak, V., Medica, V., Bukovac, O.: Simulation of a two-stroke slow speed diese engine using a quasi-dimensional model, Transactions of FAMENA Vol.40, No.2, p. 35-44, 2016. https://doi.org/10.21278/TOF.40203

[2] Ryu, Y., Lee, Y., Nam, J.: Performance and emission characteristics of additives enhanced heavy fuel oil in large two-stroke marine diesel engine, Fuel 182, p. 850-856, 2016. https://doi.org/10.1016/j.fuel.2016.06.029

[3] Mrzljak, V., Medica, V., Bukovac, O.: Volume agglomeration process in quasidimensional direct injection. https://doi.org/10.1016/j.energy.2016.09.055

[4] Fernández, I. A., Gómez, M. R., Gómez, J. R., Insua, A. A. B.: Review of propulsion systems on LNG carriers, Renewable and Sustainable Energy Reviews 67, p. 1395-1411, 2017. https://doi.org/10.1016/j.rser.2016.09.095

[5] Raj, R., Ghandehariun, S., Kumar, A., Geng, J., Linwei, M.: A techno-economic study of shipping LNG to the Asia-Pacific from Western Canada by LNG carrier Journal of Natural Gas Science and Engineering 34, p. 979-992, 2016. https:// doi.org/10.1016/j.jngse.2016.07.024

[6] Chang, D., Rhee, T., Nam, K., Chang, K., Lee, D., Jeong, S.: A study on availability and safety of new propulsion systems for LNG carriers, Reliability Engineering and System Safety 93, p. 1877- 1885, 2008. https://doi.org/10.1016/j. ress.2008.03.013

[7] Senary, K., Tawfik, A., Hegazy, E., Ali, A.: Development of a waste heat recovery system onboard LNG carrier to meet IMO regulations, Alexandria Engineering Journal 55, Issue 3, p. 1951-1960, 2016. https://doi.org/10.1016/j.aej.2016.07.027

[8] Vanem, E., Antao, P., Østvik, I., Del Castillo de Comas, F.: Analysing the risk of LNG carrier operations, Reliability Engineering and System Safety 93, p. 1328-1344, 2008. https://doi.org/10.1016/j.ress.2007.07.007

[9] Zhao, F., Yang, W., Tan, W. W., Yu, W., Yang, J., Chou, S. K.: Power management of vessel propulsion system for thrust efficiency and emissions mitigation, Applied Energy 161, p. 124-132, 2016. https://doi.org/10.1016/j.apenergy.2015.10.022

[10] Trivyza, N. L., Rentizelas, A., Theotokatos, G.: A novel multi-objective decision support method for ship energy systems synthesis to enhance sustainability, Energy Conversion and Management 168, p. 128-149, 2018. https://do org/10.1016/j.enconman.2018.04.020

[11] Dorosz, P., Wojcieszak, P., Malecha, Z.: Exergetic Analysis, Optimization and Comparison of LNG Cold Exergy Recovery Systems for Transportation, Entropy 20(1), 59, 2018. https://doi.org/10.3390/e20010059

[12] Mrzljak, V., Poljak, I., Medica-Viola, V.: Dual fuel consumption and efficiency of marine steam generators for the propulsion of LNG carrier, Applied Thermal Engineering 119, p. 331-346, 2017. https://doi.org/10.1016/j. applthermaleng.2017.03.078

[13] Mrzljak, V., Prpić-Oršić, J., Senčić, T.: Change in Steam Generators Main and Auxiliary Energy Flow Streams During the Load Increase of LNG Carrier Steam Propulsion System, Scientific Journal of Maritime Research 32, p. 121-131, 2018. https://doi.org/10.31217/p.32.1.15

[14] Wang, C., Zhu, Y.: Entransy analysis on boiler air pre-heater with multi-stage LHS unit, Applied Thermal Engineering 130, p. 1139-1146, 2018. https://doi. org/10.1016/j.applthermaleng.2017.11.085

[15] Hajebzadeh, H., Ansari, A. N. M., Niazi, S.: Mathematical modeling and validation of a $320 \mathrm{MW}$ tangentially fired boiler: A case study, Applied Thermal Engineering 146, p. 232-242, 2019. https://doi.org/10.1016/j.applthermaleng.2018.09.102
[16] Mrzljak, V., Poljak, l., Mrakovčić, T.: Energy and exergy analysis of the turbogenerators and steam turbine for the main feed water pump drive on LNG carrier, Energy Conversion and Management 140, p. 307-323, 2017. https://doi. org/10.1016/j.enconman.2017.03.007

[17] Mrzljak, V., Senčić, T., Žarković, B.: Turbogenerator Steam Turbine Variation in Developed Power: Analysis of Exergy Efficiency and Exergy Destruction Change, Modelling and Simulation in Engineering 2018. https://doi. org/10.1155/2018/2945325

[18] Hafdhi, F., Khir, T., Ben Yahyia, A., Ben Brahim, A.: Energetic and exergetic analysis of a steam turbine.https://doi.org/10.1016/j.enconman.2015.10.044

[19] Mrzljak, V.: Low power steam turbine energy efficiency and losses during the developed power variation, Technical Journal 12 (3), p. 174-180, 2018. https:// doi.org/10.31803/tg-20180201002943

[20] Medica-Viola, V., Pavković, B., Mrzljak, V.: Numerical model for on-condition monitoring of condenser in coal-fired power plants, International Journal of Heat and Mass Transfer 117, p. 912-923, 2018. https://doi.org/10.1016/j. ijheatmasstransfer.2017.10.047

[21] Baawain, M., Choudri, B. S., Ahmed, M., Purnama, A.: Recent Progress in Desalination, Environmental and Marine Outfall Systems, Springer International Publishing Switzerland, 2015. https://doi.org/10.1007/978-3-319-19123-2

[22] Mrzljak, V., Poljak, I., Medica-Viola, V.: Efficiency and losses analysis of low-pressure feed water heater in steam propulsion system during ship maneuvering period, Scientific Journal of Maritime Research 30, p. 133-140, 2016. (https://hrcak.srce.hr/171454)

[23] Mrzljak, V., Poljak, I., Medica-Viola, V.: Energy and Exergy Efficiency Analysis of Sealing Steam Condenser in Propulsion System of LNG Carrier, International Journal of Maritime Science \& Technology "Our Sea" 64 (1), p. 20-25, 2017. https://doi.org/10.17818/NM/2017/1.4

[24] Cengel Y., Boles M.: Thermodynamics an engineering approach, Eighth edition, McGraw-Hill Education, 2015.

[25] Moran M., Shapiro H., Boettner, D. D., Bailey, M. B.: Fundamentals of engineering thermodynamics, Seventh edition, John Wiley and Sons, Inc., 2011.

[26] Burin, E. K., Vogel, T., Multhaupt, S., Thelen, A., Oeljeklaus, G., Gorner, K., Bazzo, E.: Thermodynamic and economic evaluation of a solar aided sugarcane bagasse cogeneration power plant, Energy 117, Part 2, p. 416-428, 2016. https://doi. org/10.1016/j.energy.2016.06.071

[27] Kowalczyk, T., Ziółkowski, P., Badur, J.: Exergy Losses in the Szewalski Binary Vapor Cycle, Entropy 17, p. 7242-7265, 2015. https://doi.org/10.3390/e17107242

[28] Mrzljak, V., Poljak, I., Medica-Viola, V.: Thermodynamical analysis of high-pressure fed water heater in steam propulsion system during exploitation, Shipbuilding: Theory and Practice of Naval Architecture, Marine Engineering and Ocean Engineering 68 (2), p. 45-61, 2017.https://doi.org/10.21278/brod68204

[29] Sutton, I.: Plant Design and Operations, Elsevier Inc., 2015.

[30] Mrzljak, V., Poljak, l., Žarković, B.: Exergy Analysis of Steam Pressure Reduction Valve in Marine Propulsion Plant on Conventional LNG Carrier, International Journal of Maritime Science \& Technology "Our Sea" 65(1), p. 24-31, 2018. https://doi.org/10.17818/NM/2018/1.4

[31] Koroglu, T., Sogut, O. S.: Conventional and Advanced Exergy Analyses of a Marine Steam Power Plant, Energy 163, p. 392-403, 2018. https://doi. org/10.1016/j.energy.2018.08.119

[32] Yildirim, N., Genc, S.: Energy and exergy analysis of a milk powder production system, Energy Conversion and Management 149, p. 698-705, 2017. https://doi. org/10.1016/j.enconman.2017.01.064

[33] Tan, H., Shan, S., Nie, Y., Zhao, Q.: A new boil-off gas re-liquefaction system for LNG carriers based on dual mixed refrigerant cycle, Cryogenics 92, p. 84-92, 2018. https://doi.org/10.1016/j.cryogenics.2018.04.009

[34] Orović, J., Mrzljak, V., Poljak, l.: Efficiency and Losses Analysis of Steam Air Heater from Marine Steam. https://doi.org/10.3390/en11113019

[35] Ahmadi, G., Toghraie, D., Akbari, O. A.: Solar parallel feed water heating repowering of a steam power plant: A case study in Iran, Renewable and Sustainable Energy Reviews 77, p. 474-485, 2017. https://doi.org/10.1016/j.rser.2017.04.019

[36] Ahmadi, G. R., Toghraie, D.: Energy and exergy analysis of Montazeri Steam Power Plant in Iran, Renewable and Sustainable Energy Reviews 56, p. 454-463, 2016. https://doi.org/10.1016/j.rser.2015.11.074

[37] Poljak, I., Orović, J., Mrzljak, V.: Energy and Exergy Analysis of the Condensate Pump During Internal Leakage from the Marine Steam Propulsion System, Scientific Journal of Maritime Research 32 (2), p. 268-280, 2018. (doi:10.31217/p.32.2.12)

[38] Taner, T., Sivrioglu, M.: Energy-exergy analysis and optimisation of a model sugar factory in Turkey, Energy 93, p. 641-654, 2015. https://doi.org/10.1016/j. energy.2015.09.007

[39] Marine Steam Turbine MS40-2 - Instruction Book For Marine Turbine Unit, HYUNDAI-MITSUBISHI, HYUNDAI HEAVY INDUSTRIES CO., LTD., ULSAN, KOREA, 2004., internal ship documentation

[40] Cangioli, F., Chatterton, S., Pennacchi, P., Nettis, L., Ciuchicchi, L.: Thermo-elasto bulk-flow model for labyrinth seals in steam turbines, Tribology International 119, p. 359-371, 2018. https://doi.org/10.1016/j.triboint.2017.11.016

[41] Lemmon, E.W., Huber, M.L., McLinden, M.O.: NIST reference fluid thermodynamic and transport properties-REFPROP, version 9.0, User's guide, Colorado, 2010.

[42] http://www.industriascontrolpro.com (accessed: 18.10.2018)

[43] https://www.greisinger.de (accessed: 18.10.2018)

[44] http://www.krtproduct.com (accessed: 20.10.2018) 